\title{
Effect of Reaction Parameters on the Production of Cyclodextrin using Cyclodextrin Glucanotransferase from Bacillus licheniformis
}

\author{
Rohaida Che Man 1,, Shalyda Md. Shaarani@Nawi'1, Zatul Iffah Mohd Arshad², Siti Kholijah Abdul Mudalip ${ }^{1,3}$, Siti Zubaidah \\ Sulaiman ${ }^{1}$, Aizi Nor Mazila Ramli
}

\author{
1 Department of Chemical Engineering, College of Engineering, Universiti Malaysia Pahang, Lebuhraya Tun Razak, 26300 Gambang, Pahang, \\ Malaysia \\ ${ }^{2}$ Faculty of Chemical and Process Engineering Technology, College of Engineering Technology, Universiti Malaysia Pahang, Lebuhraya Tun \\ Razak, 26300 Gambang, Pahang, Malaysia \\ ${ }^{3}$ Centre of Excellence for Advanced Research in Fluid Flow (CARIFF), Universiti Malaysia Pahang, Lebuhraya Tun Razak, 26300 Gambang, \\ Pahang, Malaysia \\ ${ }^{4}$ College of Computing and Applied Sciences, Faculty of Industrial Sciences and Technology, Universiti Malaysia Pahang, Lebuhraya Tun Razak, \\ Gambang, 26300 Gambang, Pahang, Malaysia.
}

\begin{abstract}
Cyclodextrin glucanotransferase (CGTase) is an industrial enzyme that converts starch into cyclodextrin (CD). CD has many potential applications in wide range of industries including food, cosmetic, pharmaceutical and plastic industries. Production of CD from CGTase is based on a few process parameters such as concentration of substrate, types of substrate, reaction time, pH and temperature. In this present study, the effect of types of substrate (corn, potato, wheat, rice and tapioca starch), concentration of substrate $(1,2,3,4,5,6,7,8$ and $9 \%)$ and reaction time $(1,2,3,4$ and $5 \mathrm{hr})$ on the CD production using commercial CGTase from Bacillus licheniformis were studied. Among the five types of substrate tested, the potato starch was the most suitable substrate for the production of CD with $10.24 \mathrm{mg} / \mathrm{ml}$ of CD. In addition, by using $6 \%$ (w/v) of potato starch, the production of CD was $15.16 \mathrm{mg} / \mathrm{ml}$. The optimal reaction time was found to be $4 \mathrm{hr}$ with $12.41 \mathrm{mg} / \mathrm{ml}$ of $\mathrm{CD}$. Therefore, the best reaction parameters proved to be valuable for the highest CD production. Hence, CGTase from Bacillus licheniformis was demonstrated to produce high CD at optimum reaction conditions and it has potential to be used in large scale production for the industrial purposes.
\end{abstract}

\section{KEYWORDS}

Bacillus licheniformis, cyclodextrin glucanotransferase, cyclodextrin, types of substrate, concentration of substrate, reaction time.

\section{INTRODUCTION}

CD is produced by the enzymatic reaction between cyclodextrin glucanotransferase (CGTase) and starch (Hao et al., 2017; Fenelon et al., 2018). The other types of substrate used in the CD production are dextrin, amylose, glycogen and amylopectin (Valle, 2004). CD can be divided into three different types which are $\alpha-C D, \beta-C D$ and $\gamma$-CD (Jansook et al., 2018; Fernández et al., 2019). CD consist of hydrophilic surface outside and hydrophobic surface inside which enabling it to form inclusion complexes with organic and inorganic molecules. This allow CD to reduce side effects of drug formulations and to eliminate any unwanted flavours and aroma as well as to keep the guest molecules from degradation under the action of light and heat (Chen et al., 2019). CD has been discovered to have numerous application in the food, cosmetic, pharmaceutical and plastic industries.

CGTase is a unique enzyme produced by the microorganisms, usually Bacillus sp. (Rather et al., 2015). It is also called as cyclomaltodextrin glucanotransferase, cyclomaltodextrin glycosyltransferase or cyclodextrin glycosyltransferase (Qi and Zimmermann, 2005). CGTase is owned by the transferase enzymes group (EC 2.4.1.19) and classified as hexosyltransferase. It hydrolyze the starch and also catalyzes the reactions of transglycosylation. CGTase is mostly used in food and pharmaceutical industries (Jamil et al., 2018; Suhaimi et al., 2018). Generally, CGTase was produced from various sources such as from Bacillus obhensis, Klebsiella pneumonia, Bacillus agaradhaerens and Klebsiella pneumonia. In this present study, commercial CGTase was produced by Bacillus licheniformis.

The reaction parameters of CGTase such as types of substrate, concentration of substrate, reaction time, $\mathrm{pH}$ and temperature will affect the production of $\mathrm{CD}$. The effect of temperature $\left(70\right.$ and $\left.90^{\circ} \mathrm{C}\right)$ on the production of $\mathrm{CD}$ using CGTase from Thermoanaerobacter sp. was studied by Schöffer et al. (2013). The study found that the highest production of $\mathrm{CD}$ was obtained at $90^{\circ} \mathrm{C}$ with $4.93 \mathrm{mg} / \mathrm{ml}$ of CD. Meanwhile, the lowest CD production $(0.72 \mathrm{mg} / \mathrm{ml})$ was detected at $70{ }^{\circ} \mathrm{C}$ of temperature. The temperature has important effect on $\mathrm{CD}$ production by enhancing the interaction between enzyme and substrate molecules.

The reaction time also has a major influence on the production process. Qiu et al. (2018) discussed the influence of reaction time on the $\mathrm{CD}$ production using CGTase from recombinant $E$. coli. The longer the reaction time, the higher is 
the yield of CD. The CD yield increased slowly with the passing of time and the highest yield of about $10 \%$ was obtained after $21 \mathrm{hr}$.

The effect of substrate on the production of CD has shown to be extremely important. The effect of substrate on CD production using CGTase from Bacillus firmus strain 37 was carried out by Fenelon et al. (2015). The maltodextrin substrate with a $10 \%(\mathrm{w} / \mathrm{v})$ of concentration produced $11.9 \mathrm{mmol} / 1$ of CD. Meanwhile, $5 \%(\mathrm{w} / \mathrm{v})$ of corn starch substrate gave a higher CD production with $13.5 \mathrm{mmol} / \mathrm{l}$ of $\mathrm{CD}$. The different composition of amylose and amylopectin in different types of substrate affected the production of CD.

Most studies discussed the effect of reaction parameters on the CD production using CGTase from various sources such as Thermococcus sp., Thermoanaerobacter sp., Bacillus sp. and recombinant E. coli (Goh et al., 2007; Moriwaki et al., 2014). To the best of our knowledge, there have been no studies on the effect of reaction parameters on CD production using the commercial CGTase from Bacillus licheniformis. Moreover, the effect of reaction parameters such as substrate types, concentration of substrate and reaction time on the CD production by using commercial CGTase from Bacillus licheniformis has not been investigated. Therefore, the effect of types of substrate, concentration of substrate and reaction time on the CD production by using commercial CGTase from Bacillus licheniformis was investigated in this present study.

\section{MATERIALS AND METHODS}

\section{Materials}

Commercial CGTase from Bacillus licheniformis (Toruzyme 3.0) was purchased from Novozymes A/S (Bagsvaerd, Denmark). Acetonitrile, methanol, sodium hydroxide, sodium dihydrogen phosphate, glycine, and soluble potato starch were purchased from Merck Sdn Bhd (Darmstadt, Germany). Soluble potato, corn, tapioca, wheat and rice starch were purchased from Chemolab Supplies Sdn Bhd (Selangor, Malaysia).

\section{Effect of reaction parameters on synthesis of CD using CGTase from Bacillius licheniformis}

\section{Types of substrate}

The substrates used in this study were corn, potato, rice, wheat and tapioca starch. About $20 \mathrm{ml}$ of soluble starch solution with concentration of 3\% (w/v) (Suhaimi, 2019) was prepared in $50 \mathrm{mM}$ sodium phosphate buffer ( $\mathrm{pH} 6.0$ ) by gelatinize in a steam water bath for $10 \mathrm{~min}$ and the solution was allowed to cool at room temperature. After that, 0.1 $\mu \mathrm{g} / \mathrm{ml}$ of CGTase was added to the sample and incubated with agitation rate of $100 \mathrm{rpm}$ and $40^{\circ} \mathrm{C}$ of temperature for 4 $\mathrm{hr}$ of reaction time. The experiments were conducted in three replicates. The sample was analyzed using High Performance Liquid Chromatography (HPLC).

\section{Substrate concentration}

Effect of substrate concentration on the synthesis of CD was investigated using different concentration of 1, 2, 3, 4, 5, $6,7,8$ and $9 \%$ (w/v) (Ibrahim et al., 2011). About $20 \mathrm{ml}$ of soluble potato starch solution was prepared in $50 \mathrm{mM}$ sodium phosphate buffer ( $\mathrm{pH}$ 6.0) by gelatinize in a steam water bath for $10 \mathrm{~min}$ and the solution was allowed to cool at room temperature. Then, $0.1 \mu \mathrm{g} / \mathrm{ml}$ of CGTase was added to the sample and incubated in the incubator shaker with agitation rate of $100 \mathrm{rpm}$ at $40^{\circ} \mathrm{C}$ of temperature for $4 \mathrm{hr}$ of reaction time. All experiments were conducted in three replicates. The sample was analyzed using High Performance Liquid Chromatography (HPLC).

\section{Reaction time}

Effect of reaction time on the production of CD using CGTase from Bacillus licheniformis was conducted at various reaction times of 1, 2, 3, 4 and $5 \mathrm{hr}$ (Rahim et al. 2015). About $20 \mathrm{ml}$ of soluble potato starch solution with concentration of $6 \%(\mathrm{w} / \mathrm{v})$ was prepared in $50 \mathrm{mM}$ sodium phosphate buffer $(\mathrm{pH} \mathrm{6.0)}$ by gelatinize in a steam water bath for $10 \mathrm{~min}$ and the solution was allowed to cool at room temperature. Then, $0.1 \mu \mathrm{g} / \mathrm{ml}$ of CGTase was added to the sample and incubated in the incubator shaker with agitation rate of $100 \mathrm{rpm}$ and $40^{\circ} \mathrm{C}$ of temperature. The experiments were conducted in three replicates. The sample was analyzed using High Performance Liquid Chromatography (HPLC).

\section{Analytical Analysis}

\section{High performance liquid chromatography (HPLC)}

The concentration of $\mathrm{CD}$ was determined by using high performance liquid chromatography (HPLC) with quaternary pump (Agilent 1260 Infinity Binary LC, California, USA). The column used was Zorbax Eclipse Plus C18, $150 \mathrm{~mm} \mathrm{x}$ $4.6 \mathrm{~mm}$ (Agilent Technologies, California, USA). The mobile phase is a mixture of acetonitrile: water (60:40) at $1 \mathrm{ml} / \mathrm{min}$. The reflective index detector was used to detect the $\mathrm{CD}$. The temperature of column was set at $30^{\circ} \mathrm{C}$. All the samples 
were filtered with a nylon membrane filter $(0.2 \mu \mathrm{m}$ pore size) with diameter of $13 \mathrm{~mm}$ before injection (Sakinah et al., 2014).

\section{EXPERIMENTAL RESULTS}

\section{Effect of Types of Substrate on the Synthesis of CD}

The effect of starch types on the synthesis of CD was investigated as shown in Figure 1. The highest CD production up to $10.24 \mathrm{mg} / \mathrm{ml}$ was detected when the potato starch was used as a substrate. This is due to the highest content of amylopectin in the potato starch compared to other starches (Zhao et al., 2018). The production of CD is depends on the content of amylopectin or amylose of the substrate. Different substrate contains different composition of amylopectin or amylose. The amylopectin contains high branched structure. Meanwhile, the amylose consists of long linear chains structure. The high content of amylopectin is preferred because of more content of $\alpha-1,4$-glycosidic bonds (Jeong et al., 2019 ) that assisted in the production of CD. The $\alpha-1,4$-glycosidic bonds were cleaved by CGTase between subsite +1 and -1 of the substrate and produced glycosyl-intermediate as shown in Figure 2. Then, the glyosyl-intermediate was formed the hydroxyl group and new $\alpha-1,4$-glycosidic bond was produced to form cyclic of CD. This proved that high amount of amylopectin formed high content of $\alpha-1,4$-glycosidic bonds that contributed in the production of CD. Moreover, the amylopectin with high branched structure allowed the reaction of CGTase occurred at numerous points of substrate, thus greatly enhanced the CD (Leemhuis et al., 2010). In the present study, the potato starch contained the highest amount of amylopectin (about 78\%) compared to other starches (Chen et al., 2004). Hence, this proved that the high content of amylopectin contributed in the high production of CD.

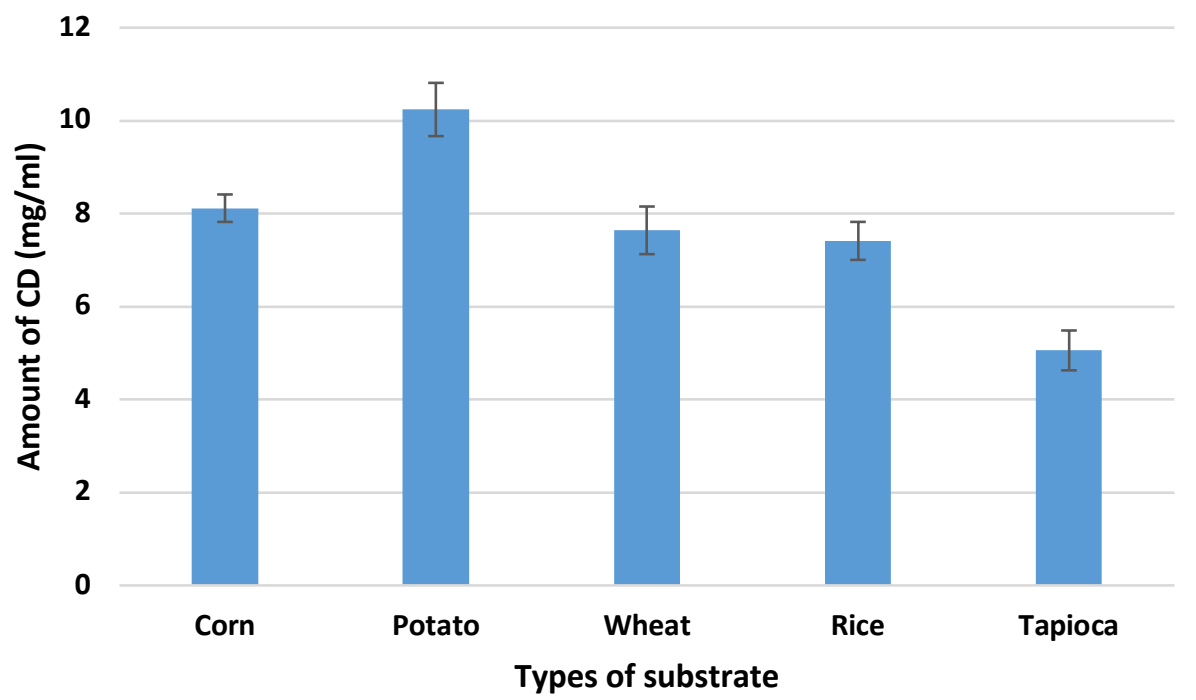

Figure 1. Effect of types of substrate on the synthesis of CD using $0.1 \mu \mathrm{g} / \mathrm{ml}$ of CGTase. About $3 \%$ (w/v) of substrate was prepared in $50 \mathrm{mM}$ sodium phosphate buffer $(\mathrm{pH}$ 6.0). The conditions for reaction were as follows: 4 hr of reaction time, $100 \mathrm{rpm}$ and $40^{\circ} \mathrm{C}$.

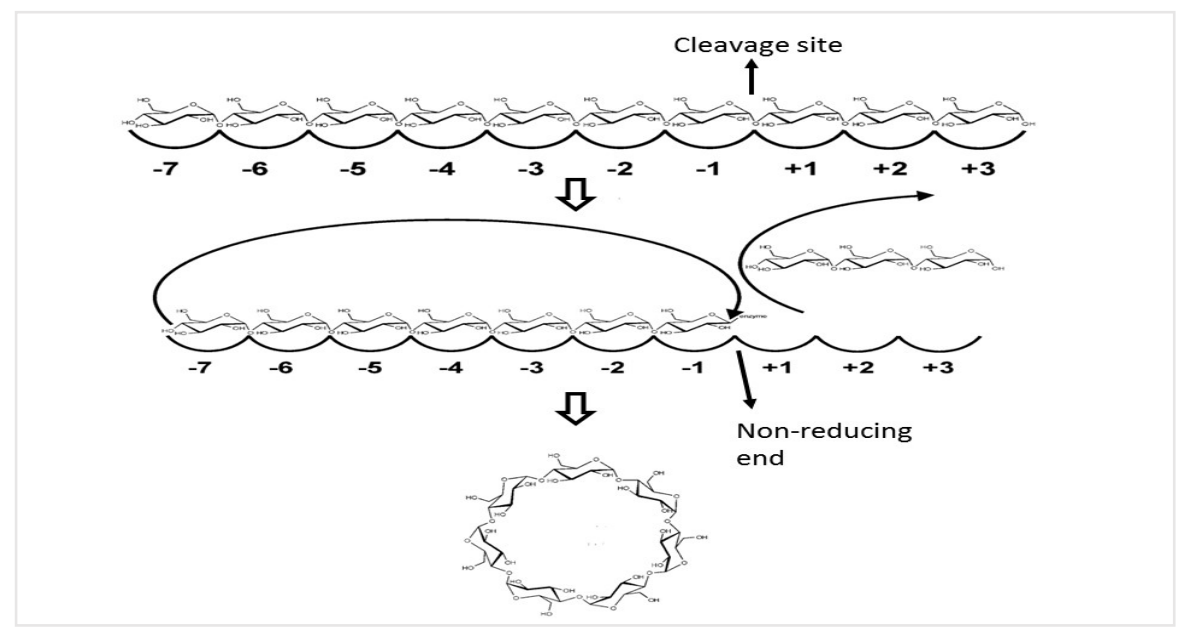

Figure 2. Schematic view of CD formation using CGTase (Source: Leemhuis et al., 2010) 
A study investigated by Duan et al. (2013) using CGTase from recombinant $E$. coli also showed that the potato starch that consists of high content of amylopectin produced high amount of CD. The total yield of CD was $84.6 \%$ (w/w) after $24 \mathrm{hr}$ of reaction time. Moreover, the findings in the present study was also similar with the results obtained by Cheirsilp et al. (2010). In this study, potato starch was also the best substrate for the production of CD using CGTase from Bacillus sp. C26. It was reported that the high amylopectin content in the potato starch assisted in the production of CD. The amylopectin with highly branched structure allowed the reaction of enzyme to start from various points. Therefore, in this present study, the potato starch was selected as the best substrate to be used for the subsequent study due to the high production of CD.

\section{Effect of substrate concentration (potato starch) on the synthesis of CD}

The effect of soluble potato starch on the synthesis of CD was investigated using different concentration of $1,2,3,4$, $5,6,7,8$, and $9 \% \mathrm{w} / \mathrm{v}$ (Figure 3$)$. The high production of CD $(15.16 \mathrm{mg} / \mathrm{ml})$ was obtained when $6 \%(\mathrm{w} / \mathrm{v})$ of substrate was used. This occurrence because of high content of amylopectin in high concentration of potato starch (Weil et al., 2020). Therefore, the CGTase reacted with the highly branched amylopectin at numerous points and resulted in high production of CD. Further increase the concentration of soluble potato starch above $6 \%$ resulted in decrease of CD production. This phenomenon happened due to the saturation of starch binding on the enzyme active site, thus affected the production of CD (Sakinah et al., 2014).

The study conducted by Rakmai et al. (2015) showed that the CD production using CGTase from Bacillus sp. C26 increased with an increasing the starch concentration from $1 \%$ to $4 \%$. Nevertheless, the CD production was not significantly different when the concentration of starch was further increased up to $8 \%$. The reaction process for production of CD was reversible and the production of CD was prevented if high product concentration was obtained. Moreover, the high starch concentration in the reaction mixture increased the viscosity and this phenomenon obstructed the binding process of enzyme and substrate.

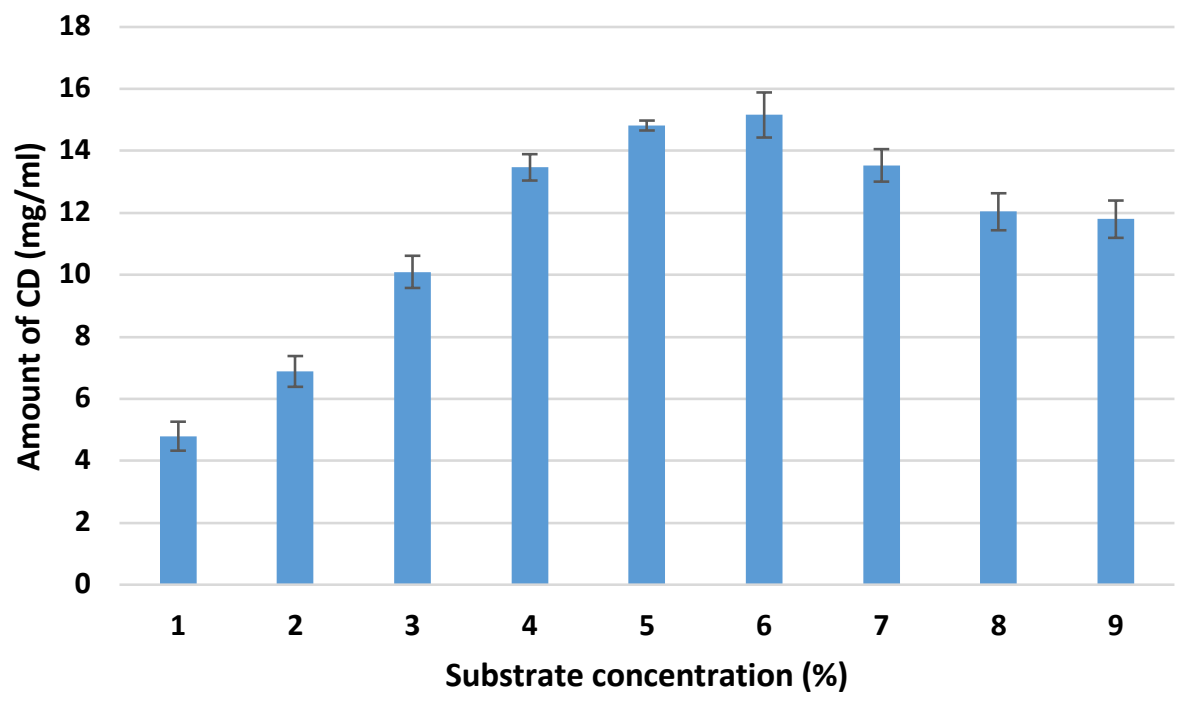

Figure 3. Effect of substrate concentration on the synthesis of CD using $0.1 \mu \mathrm{g} / \mathrm{ml}$ of CGTase. The potato starch was used as substrate and it was prepared in $50 \mathrm{mM}$ sodium phosphate buffer $(\mathrm{pH} 6.0)$. The reaction conditions were $4 \mathrm{hr}$ of reaction time, $100 \mathrm{rpm}$ of agitation rate and $40^{\circ} \mathrm{C}$ of temperature.

A study conducted by Rajput et al. (2016) on the production of CD using CGTase from Alkaliphile Microbacterium terrae KNR 9 showed that increased in the potato starch concentration has favourable impact on the production of CD. The CD production was optimum using $150 \mathrm{gm} / 1$ of potato starch concentration with $28.22 \mathrm{gm} / 1$ of CD. However, further increased the concentration of potato starch caused low production of $\mathrm{CD}$. This occurrence due to the high potato starch concentration lead to the high viscosity in a reaction mixture, thus affecting difficulty in stirring and hinders the substrate binding to the enzyme active site (Schöffer et al. 2013).

As a conclusion, $6 \%$ of potato starch concentration was chosen as the optimal concentration in the present study because of high production of $\mathrm{CD}$. The use of low concentration of potato starch could also decrease the production cost of CD. 


\section{Effect of reaction time on the synthesis of CD}

Figure 4 shows the effect of reaction time on the synthesis of CD by different reaction time (1, 2, 3, 4, and $5 \mathrm{hr})$. The production of CD was improved significantly by increasing the reaction time from 1 to $4 \mathrm{hr}$. The CD production was $12.41 \mathrm{mg} / \mathrm{ml}$ at $4 \mathrm{hr}$ of reaction time. The CD increment occurred when the reaction time was increased due to the frequent binding between tapioca starch and enzyme, thus improved the reaction process for the production of CD (Ibrahim, 2013). The results from Schöffer et al. (2017) was similar with the findings from the present study on the production of CD using CGTase from Thermoanaerobacter sp. Reduction in the concentration of CD was observed when increasing the reaction time for reaction process. It might be due to the usage of CD as a substrate whereby the CGTase is able to catalyze the $\alpha$ (1-4) bonds hydrolysis and disproportionation, besides capable to involve in the transglycosylation and cyclization reactions. Moreover, Terada et al. (1997) reported that the CGTase firstly able to produce larger CD when reacted with starch, then capable to reduce the size of CD after the reaction process.

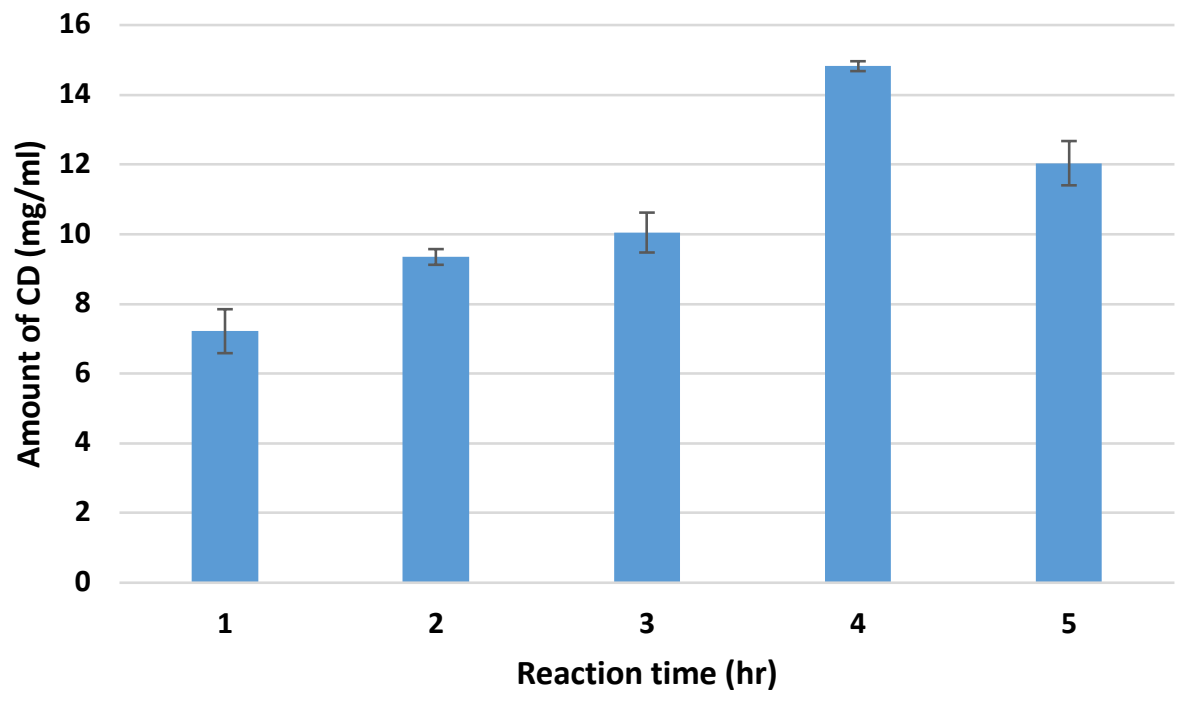

Figure 4. Effect of reaction time on the synthesis of CD using $0.1 \mu \mathrm{g} / \mathrm{ml}$ of CGTase with potato starch was used as a substrate. About $6 \%(\mathrm{w} / \mathrm{v})$ of substrate was prepared in $50 \mathrm{mM}$ sodium phosphate buffer $(\mathrm{pH} 6.0)$. The conditions for reaction were $100 \mathrm{rpm}$ of agitation rate and $40^{\circ} \mathrm{C}$ of temperature.

Slightly decrease in the CD production was detected when the reaction time was prolonged. The CD was $12.04 \mathrm{mg} / \mathrm{ml}$ at $5 \mathrm{hr}$ of reaction time. The inhibition of product occurred when CD accumulated in the reaction mixture. The CD would accumulate on the enzyme active site and avoid the binding process of the substrate to the enzyme active site. Thus, this occurrence affected the production of CD production.

A study carried out by Charoenlap et al. (2004) on CD production using CGTase from Bacillus circulans (TISTR 907) with the sago starch as a substrate showed that the CD production was maximum $(4.33 \mathrm{mg} / \mathrm{ml})$ at $9 \mathrm{hr}$ of reaction time. However, the CD production at $6 \mathrm{hr}$ and $9 \mathrm{hr}$ of reaction time were not significantly different with $4.05 \mathrm{mg} / \mathrm{ml}$ of $\mathrm{CD}$ was detected at $6 \mathrm{hr}$ of reaction time. For economic point of view, $6 \mathrm{hr}$ of reaction time was selected as the optimum reaction time for the production of $\mathrm{CD}$.

Therefore, $4 \mathrm{hr}$ of reaction time was selected as the optimal reaction time in this present study as it requires less time to produce maximum amount of CD. Moreover, sufficient time allows the starch to bind more frequently and extensively on the enzyme, thus increased the enzymatic reaction for the production of CD. Shorten time required for the reaction process of CGTase for high CD production gave significant advantage to be used in the industrial scale production.

\section{CONCLUSION}

The influence of reaction parameters (starch types, potato starch concentration and reaction time) of CGTase from Bacillus licheniformis on CD production have been successfully investigated. This study showed the best type of substrate for the production of $\mathrm{CD}$ was the soluble potato starch. In addition, the production of CD was optimum using $6 \%$ (w/v) of potato starch and $4 \mathrm{hr}$ of reaction time. In conclusion, the best reaction parameters of commercial CGTase from Bacillus licheniformis capable to improve the $\mathrm{CD}$ production and could be a promising approach for the application in various industries.

\section{ACKNOWLEDGMENT}

The study was financially supported by Universiti Malaysia Pahang (Grant No: RDU182305). The authors are grateful to the Faculty of Chemical and Process Engineering Technology for supporting and providing the laboratory facilities. 


\section{REFERENCES}

Charoenlap, N., Dharmsthiti, S., Sirisansaneeyakul, S., \& Lertsiri, S. (2004). Optimization of cyclodextrin production from sago starch. Bioresource Technology, 92(1), 49-54. https://doi.org/10.1016/j.biortech.2003.07.007

Cheirsilp, B., Kitcha, S., \& Maneerat, S. (2010). Kinetic characteristics of $\beta$-cyclodextrin production by cyclodextrin glycosyltransferase from newly isolated Bacillus Sp. C26. Electronic Journal of Biotechnology, 13(4), 4-5. https://doi.org/10.2225/vol13-issue4-fulltext-6

Chen, H., Li, L., Ma, Y., Mcdonald, T.P, \& Wang, Y. (2019). Development of active packaging film containing bioactive components encapsulated in $\beta$-cyclodextrin and its application. Food Hydrocolloids, 90, 360-66. https://doi.org/10.1016/j.foodhyd.2018.12.043

Chen, Z., Schols, H.A., \& Voragen, A.G.J (2004). Differently sized granules from acetylated potato and sweet potato starches differ in the acetyl substitution pattern of their amylose populations. Carbohydrate Polymers, 56(2), 219-26. https://doi.org/10.1016/j.carbpol.2004.02.004

Schöffer, J.D.N, Klein, M.P., Rodrigues, R.C., \& Hertz, P.F. (2013). Continuous production of $\beta$-cyclodextrin from starch by highly stable cyclodextrin glycosyltransferase immobilized on chitosan. Carbohydrate Polymers, 98(2) 1311-1316. https://doi.org/10.1016/j.carbpol.2013.07.044

Schöffer, J.D.N, Matte, C.R., Charqueiro, D.S., de Menezes, E.W., Costa, T.M.H., Benvenutti, E.V., Rodrigues, R.C., \& Hertz, P.F. (2017). Effects of immobilization, $\mathrm{pH}$ and reaction time in the modulation of $\alpha$-, $\beta$-or $\gamma$-cyclodextrins production by cyclodextrin glycosyltransferase: batch and continuous process. Carbohydrate Polymers, 169, 41-49. https://doi.org/10.1016/j.carbpol.2017.04.005

Duan, X., Chen, S., Chen, J., \& Wu, J. (2013). Enhancing the cyclodextrin production by synchronous utilization of isoamylase and $\alpha-$ CGTase. Applied Microbiology and Biotechnology, 97(8), 3467-3474. https://doi.org/ 10.1007/s00253-012-4292-9

Fenelon, V.C., Miyoshi, J.H., Mangolim, C.S., Noce, A.S., Koga, L.N., \& Matioli, G. (2018). Different strategies for cyclodextrin production: ultrafiltration systems, CGTase immobilization and use of a complexing agent. Carbohydrate Polymers, 192, 1927. https://doi.org/10.1016/j.carbpol.2018.03.035

Goh, K.M., Mahadi, N.M., Hassan, O., Rahman, R.N.Z.R.A., \& Illias, R. M. (2007). The effects of reaction conditions on the production of $\gamma$-cyclodextrin from tapioca starch by using a novel recombinant engineered CGTase. Journal of Molecular Catalysis B: Enzymatic, 49(1), 118-26. https://doi.org/10.1016/j.molcatb.2007.09.011

Ibrahim, A.S., El-Tayeb, M.A., Elbadawi, Y.B., \& Al-Salamah, A.A. (2011). Effects of substrates and reaction conditions on production of cyclodextrins using cyclodextrin glucanotransferase from newly isolated Bacillus agaradhaerens KSU-A11. Electronic Journal of Biotechnology, 14(5), 1-12. https://doi.org/10.2225/vol14-issue 5-fulltext-4

Ibrahim, S. (2013). Effects of enzyme concentration, temperature, $\mathrm{pH}$ and time on the degree of hydrolysis of protein extract from viscera of tuna (Euthynnus affinis) by using alcalase. Sains Malaysiana, 42(3), $279-287$. https://doi.org/10.1016/j.foodchem.2008.12.013

Jamil, N., Man, R.C., Suhaimi, S., Shaarani, S.M., Arshad, Z.I.M., Mudalip, S.K.A., \& Sulaiman, S.Z. (2018). Effect of enzyme concentration and temperature on the immobilization of cyclodextrin glucanotransferase (CGTase) on hollow fiber membrane. Materials Today: Proceedings, 5(10), 22036-42. https://doi.org/10.1016/j.matpr.2018.07.065

Jeong, H.K., Lee, D., Kim, H.P., \& Baek, S.H. (2019). Structure analysis and antioxidant activities of an amylopectin-type polysaccharide isolated from dried fruits of Terminalia chebula. Carbohydrate Polymers, 211, $100-108$. https://doi.org/10.1016/j.carbpol.2019.01.097

Leemhuis, H., Kelly, R.M., \& Dijkhuizen, L. (2010). Engineering of cyclodextrin glucanotransferases and the impact for biotechnological applications. Applied Microbiology and Biotechnology, 85(4), 823-835. https://doi.org/10.1007/s00253-0092221-3

Moriwaki, C., Mangolim, C.S., Ruiz, G.B., de Morais, G.R., Baesso, M.L., \& Matioli, (2014). Biosynthesis of CGTase by immobilized alkalophilic Bacilli and crystallization of beta-cyclodextrin: effective techniques to investigate cell immobilization and the production of cyclodextrins. Biochemical Engineering Journal, 83, 22-32. https://doi.org/10.1016/j.bej.2013.12.004

Rahim, A.S.N., Sulaiman, A., Hamid, K.H.K., Edama, N.A., \& Baharuddin, A.S. (2015). Effect of agitation speed for enzymatic hydrolysis of tapioca slurry using encapsulated enzymes in an enzyme bioreactor. International Journal of Chemical Engineering and Applications, 6(1), 38-41. https://doi.org/10.7763/ijcea.2015.v6.447

Qi, Q., \& Zimmermann, W. (2005). Cyclodextrin glucanotransferase: from gene to applications. Applied Microbiology and Biotechnology, 66(5), 475-485. https://doi.org/10.1007/s00253-004-1781-5

Qiu, C., Wang, J., Fan, H., Bai, Y., Tian, Y., Xu, X., \& Jin, Z. (2018). High-efficiency production of $\gamma$-cyclodextrin using $\beta$-cyclodextrin as the donor raw material by cyclodextrin opening reactions using recombinant cyclodextrin glycosyltransferase. Carbohydrate Polymers, 182, 75-80. https://doi.org/10.1016/j.carbpol.2017.11.014

Rajput, K.N., Patel, K.C., \& Trivedi, U.B. (2016). $\beta$-cyclodextrin production by cyclodextrin glucanotransferase from an Alkaliphile microbacterium terrae KNR 9 using different starch substrates. Biotechnology Research International, 2016. https://doi.org/10.1155/2016/2034359

Rakmai, J., Cheirsilp, B., \& Prasertsan, P. (2015). Enhanced thermal stability of cyclodextrin glycosyltransferase in alginate-gelatin mixed gel beads and the application for $\beta$-cyclodextrin production. Biocatalysis and Agricultural Biotechnology, 4(4), 717-726. https://doi.org/10.1016/j.bcab.2015.10.002

Rather, M.Y., Ara, K.Z.G., Karlsson, E.N., \& Adlercreutz, P. (2015). Characterization of cyclodextrin glycosyltransferases (CGTases) and their application for synthesis of alkyl glycosides with oligomeric head group. Process Biochemistry, 50(5), 722-28. https://doi.org/10.1016/j.procbio.2015.02.016

Sakinah, A.M., Ismail, A.F., Illias, R.M., Zularisam, A.W., Hassan, O., \& Matsuura, T. (2014). Effect of substrate and enzyme concentration on cyclodextrin production in a hollow fibre membrane reactor system. Separation and Purification Technology, 124, 61-67. https://doi.org/10.1016/j.seppur.2014.01.005

Suhaimi, S. (2019). Synthesis of cyclodextrin (CD) using immobilized enzyme on hollow fiber membrane. Master Thesis, Universiti Malaysia Pahang.

Suhaimi, S., Man, R.C., Jamil, N., Arshad, Z.M., Shaarani, S.M., Mudalip, S.A., Sulaiman, S.Z., \& Ramli, A.N.M. (2018). Stability and reusability of cyclodextrin glucanotransferase immobilized on hollow fiber membrane. IOP Conference Series: Earth and 
Environmental Science, 185, 12002. https://doi.org/10.1088/1755-1315/185/1/012002

Terada, Y., Yanase, M., Takata, H., Takaha, T., \& Okada, S. (1997). Cyclodextrins are not the major cyclic $\alpha$-1, 4-glucans produced by the initial action of cyclodextrin glucanotransferase on amylose. Journal of Biological Chemistry, 272(25), 15729-15733. https://doi.org/10.1074/jbc.272.25.15729

Valle, E.M.M. D. (2004). Cyclodextrins and their uses: A Review. Process Biochemistry, 39(9), $1033-1046$. https://doi.org/10.1016/S0032-9592(03)00258-9

Weil, W., Weil, R.C., Keawsompong, S., Sriroth, K., Seib, P.A., \& Shi, Y.C. (2020). Pyrodextrin from waxy and normal tapioca starches: physicochemical properties. Food Hydrocolloids, 104, 105745. https://doi.org/10.1016/j.foodhyd.2020.105745

Zhao, X., Andersson, M. and Andersson, R. (2018). Resistant starch and other dietary fiber components in tubers from a high-amylose potato. Food Chemistry, 251, 58-63. https://doi.org/10.1016/j.foodchem.2018.01.028 